Acta vet. scand. $1959,1,12-18$.

From the Department of Anatomy and Histology, Royal Veterinary College, Stockholm.

\title{
A STUDY ON THE NERVE SUPPLY OF THE KNEE JOINT IN CATTLE
}

By

Lennart Nicander.

No information regarding the innervation of the knee joint in cattle could be found in the literature. The only ungulate species studied in this respect seems to be the horse. Ghetie (1939) described one branch from the N. saphenus to the femoropatellar joint and the medial femoro-tibial joint, and another branch from $\mathrm{N}$. tibialis to the lateral femoro-tibial joint. Hoffman (1953) added a constant branch from the $\mathrm{N}$. obturatorius to the medial femoro-tibial joint.

On the other hand, the nerve supply of the human knee joint has been repeatedly investigated, most recently by Gardner (1948), and branches have been described from the Nn. femoralis, saphenus, tibialis, peronaeus, and obturatorius. Gardner (1944), and Skoglund (1956) also studied the innervation of the knee joint in cats and observed several branches from the $\mathrm{N}$. femoralis, two from the $\mathrm{N}$. tibialis, and two from the $\mathrm{N}$. peronaeus.

\section{MATERIAL AND METHODS}

Dissections were performed on six knee joints from suckingcalves. The thigh and knee of four foetuses (C.R. lengths 11, 13, 15 , and $22 \mathrm{~cm}$ ) were fixed in Bouin's fluid or in sublimate-acetic acid and serial sectioned at 15 or $20 \mu$. Nerve staining was performed on the three largest series. Palmgren's new silver method was used, and the origin and distribution of all nerves reaching the knee joint were traced. The $11 \mathrm{~cm}$ stage was stained with azan. 


\section{OBSERVATIONS}

Four distinct nerves to the knee joint were found by dissection.

1) The largest nerve to the joint is given off by the N. saphenus, at the posterior border of the M. vastus medialis. It descends between the $M$. sartorius and the distal part of the $M$. semimembranosus, with the A.V. genus suprema, to the distal extremity

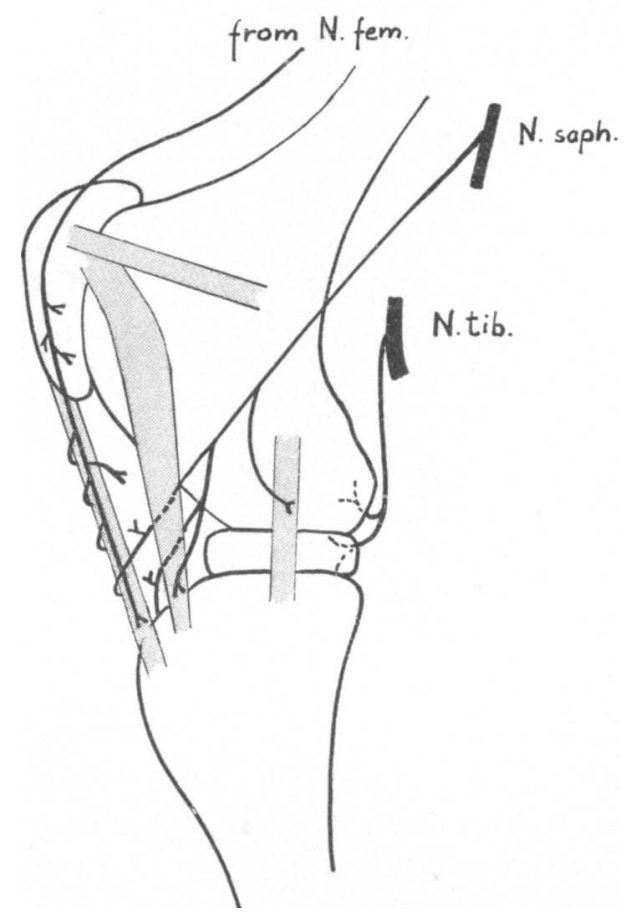

Fig. 1. Semi-schematic drawing of the nerve supply to the knee joint of a sucking-calf (medial view). The branch from the femoral nerve by way of the rectus femoris muscle, and the main branches from the saphenous nerve and from the tibial nerve are shown.

of the femur, just above the medial epicondyle. It then divides into two or three branches. The posterior branch approaches the medial collateral ligament and ramifies there, but some fibres continue into the capsule behind the ligament. The remaining parts pass downward and forward, reach the deep surface of the medial patellar ligament, which receives fibres from at least one of the branches, and then send twigs into the large fat pad behind the patellar ligaments. These bundles follow the blood vessels 


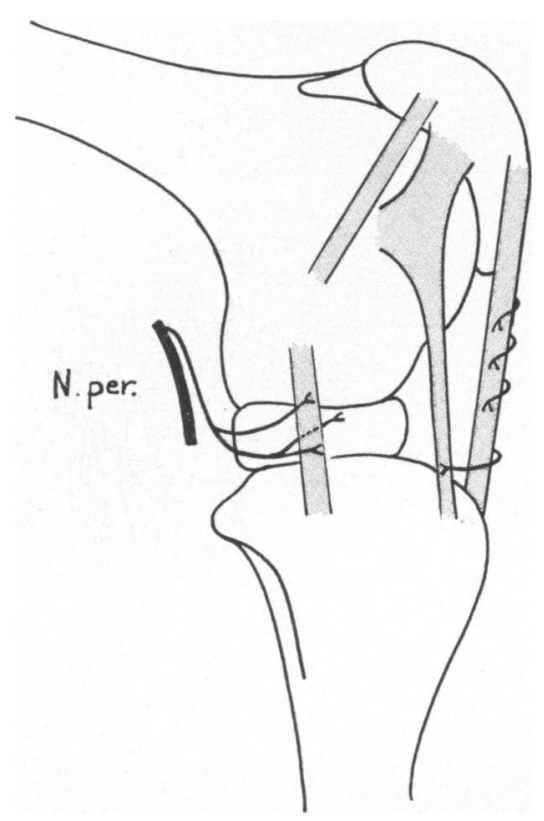

F i g. 2. Semi-schematic drawing of the knee joint of a sucking-calf (lateral view). The main articular branch of the peroneal nerve and some terminal twigs of the branch from the femoral nerve and the saphenous nerve are shown.

and one of them is distributed to the proximal extremity of the tibia along an artery. The largest branch of the nerve crosses the anterior surface of the middle patellar ligament and ultimately ramifies in the vicinity of the distal part of the lateral patellar ligament.

2) A second nerve is given off directly from the $\mathrm{N}$. femoralis to the most proximal part of the $M$. rectus femoris. It emits a few side branches in the proximal part of the muscle and then descends without further branching to the distal part of the muscle, on the anterior surface of the patella. About one centimetre proximal to the end of the fleshy part of the muscle it turns medially into the $M$. vastus medialis and continues its course across the terminal fibres of this muscle and then along the medial side of the middle patellar ligament, embedded in fat tissue. Numerous twigs are sent to the perichondrium of the anterior surface of the apex patellae and to the middle patellar ligament, and some fibres also join the vascular nerves in the 
fat pad. The terminal ramifications occur near the distal end of the ligament.

3) The posterior part of the joint capsule is principally innervated by a branch from the $\mathrm{N}$. tibialis, given off together with some large muscular branches before the nerve enters the $M$. gastrocnemius. It runs with the $\mathrm{N}$. tibialis between the two heads of the M. gastrocnemius, and then between the M. flexor digitalis superficialis and the medial head of the $M$. gastrocnemius. It turns forward in the intercondyloid fossa of the femur and divides into two, three, or four branches to the posterior capsule. They mainly form a plexus in the adventitia of the popliteal vessels, together with some other branches to be described below, and from this plexus many bundles are sent into the thick fibrous layer of the capsule, where they seem to form end-organs.

4) The N. peronaeus gives off a very fine branch at the level of the lateral epicondyle of the femur. It descends with the main stem for some distance on the lateral head of the M. gastrocnemius under cover of the $\mathrm{M}$. biceps femoris and then divides into two branches which turn forward and finally somewhat upward, approaching the lateral collateral ligament. Sometimes two separate bundles originate directly from the $\mathrm{N}$. peronaeus and follow parallel courses to the ligament. The distal branch gives fibres to the surface of the ligament through a thin layer of muscle fibres belonging to the $\mathrm{M}$. extensor digitalis lateralis. It then ramifies in the capsule along the periphery of the lateral meniscus. The proximal branch ramifies near the superficial surface of the collateral ligament at a higher level.

The section series showed some additional nerve branches to the joint not demonstrable by dissection. One or two bundles from the $\mathrm{N}$. tibialis were given off at a higher level than the main branch to the joint. They ran in the adventitia of a vein to the V. poplitea and descended with this vessel to the plexus in the intercondyloid fossa. A small bundle from the $N$. peronaeus behaved in a similar way in three foetuses. Another small bundle from the N. saphenus descended to the plexus in the adventitia of the A. poplitea. Fibres from these branches may well take part in the innervation of the posterior capsule.

Branches from the $\mathrm{N}$. femoralis to the $\mathrm{M}$. vastus intermedius and the M. articularis genu approached the wall of the suprapatellar extension of the femoro-patellar joint cavity, but no ramifications were observed in the wall. 
In one foetus two articular nerves descended in the M. rectus femoris. The smaller one followed a straight course to the surface of the middle patellar ligament and ramified between the ligament and the fascia near the apex patellae.

\section{DISCUSSION}

The innervation of the knee joint in cattle obviously shows the same main features as in humans and cats (Gardner, 1944, Skoglund, 1956). However, only one branch from the $\mathrm{N}$. femoralis is present in cattle, as a rule, whereas several branches reach the knee joint of humans, cats, and mice (Gardner, 1942) by way of the $M$. vastus medialis and the $M$. vastus lateralis. Moreover, no branch to the joint from the nerve to the $M$. rectus femoris seems to have been observed earlier. On the other hand, the joint nerve from the $N$. saphenus is unusually large in cattle and has a wide distribution. In this respect there is good agreement with the conditions in the horse (Ghetie, 1939), whereas no nerves to the stifle joint from the muscular branches of the $N$. femoralis or from the $N$. peronaeus have been described. Such nerves might be present in the horse though not demonstrable by dissection.

A constant branch from the $\mathrm{N}$. obturatorius to the stifle joint was recently described by Hoffman (1953). Contributions from this nerve are also present in humans and in cats (Gardner, 1944, Skoglund, 1956). In the present material no fibres to the knee joint from the $\mathrm{N}$. obturatorius could be found, though they were sought for in two section series comprising the whole thigh.

It is obvious that a large proportion of the nerve fibres approaching the knee joint of cattle are intended for the collateral ligaments and the middle patellar ligament. These fibres were comparatively coarse and were sometimes seen to form endings suggesting complex end-organs. Such end-organs were observed by Andrew (1954) on the surface of the medial collateral ligament of the knee joint in cats and rabbits and considered to give rise to proprioceptive impulses. Similar end-organs were probably forming in the posterior capsule in the largest foetuses, in accordance with the conditions in mice, cats, and humans (Gardner, 1942, 1944, 1948, Kellgren and Samuel, 1950, Skoglund, 1956). 


\section{REFERENCES.}

Andrew, B. L.: J. Physiol. 1954, 123, 241.

Gardner, E.: Anat. Rec. 1942, 83, 401.

- : J. comp. Neur. 1944, 80, 11.

- : Anat. Rec. 1948, 101, 109.

Ghetie, V.: Arch. Tierheilk. 1939, 75, 134.

Hoffman, G.: Monatsh. Vet. med. 1953, 8, 569.

Kellgren, J. H. and E. P. Samuel: J. Bone Joint Surg. 1950, 32 B, 84.

Palmgren, Axel: to be published in Acta Zool.

Skoglund, Sten: Acta physiol. scand. 1956, 36, Suppl. 124.

\section{SUMMARY}

The nerve supply of the knee joint in cattle was studied by dissections on sucking-calves and by nerve staining of section series of foetal joints.

Four distinct nerves to the joint were observed. They were given off by the $N$. saphenus to the medial and distal anterior regions of the joint, by a branch from the $\mathrm{N}$. femoralis within the $\mathrm{M}$. rectus femoris, to the middle patellar ligament, by the $\mathrm{N}$. tibialis to the posterior capsule, and by the $N$. peronaeus to the region of the lateral collateral ligament. The microscopical studies revealed minor additional bundles to the posterior capsular region from the N. saphenus, the N. tibialis, and the $N$. peronaeus, as well as some bundles from the $N$. femoralis to the $M$. vastus intermedius, possibly innervating the proximal part of the femoro-patellar joint capsule.

Many of the largest fibres ramified on or near the surfaces of the collateral ligaments and the middle patellar ligament.

\section{ZUSAMMENFASSUNG}

Eine Studie über die Nervenversorgung des Kniegelenks beim Rind.

Die Innervation des Kniegelenks beim Rind wurde durch Dissektion von neugeborenen Kälbern und Nervenfärbung von Schnittserien fötaler Gelenke untersucht.

Vier deutliche Nevenzweige zum Gelenk wurden wahrgenommen. Diese gingen vom $\mathbf{N}$. saphenus zum medialen und vorderen distalen Abschnitt des Gelenks, vom N. femoralis innerhalb des M. rectus femoris zum geraden Patellaband, vom $\mathbf{N}$. tibialis zu den hinteren Teilen der Kapsel und vom N. peronaeus zum lateralen Seitenband. Die mikroskopische Untersuchung ergab weiter einige kleine Bündel vom N. saphenus, N. tibialis und $\mathrm{N}$. peronaeus zu den hinteren Partien der Gelenkkapsel, sowie einige Bündel vom $N$. femoralis zum $M$. vastus intermedius, die vielleicht den proximalen Teil der Kapsel des FemoroPatellargelenks innervieren.

Viele der gröbsten Fibern verzweigten sich auf oder neben den Oberflächen der Seitenbänder und der geraden Patellabänder. 


\section{SAMMANFATTNING}

En studie av knäledens innervation hos nötkreatur.

Knäledens innervation hos nötkreatur undersöktes genom dissektion av spädkalvar och nervfärgning av snittserier från foetala leder.

Fyra tydliga nervgrenar till leden iakttogos. De utgingo från N. saphenus till ledens mediala och främre distala avsnitt, från N. femoralis inom $M$. rectus femoris till det raka patellabandet, från N. tibialis till kapselns bakre partier och från $\mathrm{N}$. peronaeus till laterala sidobandet. Den mikroskopiska undersökningen uppdagade ytterligare några små buntar från $\mathrm{N}$. saphenus, N. tibialis och $\mathrm{N}$. peronaeus till ledkapselns bakre partier, samt ett par buntar från N. femoralis till M. vastus intermedius, vilka möjligen innervera proximala delen av femoro-patellarledens kapsel.

Många av de grövsta fibrerna förgrenade sig på eller intill sidobandens och de raka patellabandens ytor.

(Received December 2. 1957). 